\title{
VÝUKA BABICTVÍ A PORODNÍ ASISTENCE V OLOMOUCI
}

\author{
Věra Vránová
}

10: $247-478,2008$

ISSN $1212-4117$

Ústav porodní asistence, Fakulta zdravotnických věd Univerzity Palackého v Olomouci

Profese porodních babiček, nyní porodních asistentek patři $\mathrm{k}$ jedněm $\mathrm{z}$ nejstarších zdravotnických oborů. Toto ,řemeslo“ se často dědilo z matky na dceru nebo jinou pŕíbuznou. Vzdělávání porodních babiček prošlo mnoha změnami. Stř́idala se období, kdy byly babičky úplně bez vzdělání, s obdobími, kdy bylo vzdělávání vysokoškolské, středoškolské a vyšší odborné. V současné době je vzdělávání porodních asistentek na úrovni vysokoškolského bakalářského studia, prípravuje se i navazující magisterské a další možností je pokračování $\mathrm{v}$ doktorském studijním programu $\mathrm{v}$ př́buzném oboru (ošetřovatelství, pedagogika, psychologie...). Př́spěvek je přehledem vzdělávání porodních babiček a porodních asistentek v Olomouci od 18. století do současnosti. Pro jeho zpracování byly informace získávány mimo jiné ze Státního okresního archívu v Olomouci a almanachů k výročí vzniku Ústavu hraběte Pöttinga v Olomouci.

V roce 1773 byla postátněna jezuitská kolej v Olomouci. Univerzita měla 3 fakulty: teologickou, filozofickou a právnickou a roku 1778 byla přeložena do Brna. Tam se na filozofické fakultě přednášela anatomie a chirurgie. Po čtyřech letech byla Brněnská univerzita zrušena a místo ní v Olomouci zrrízeno lyceum s dvouletým medicínsko-chirurgickým učením. Vzniklá škola vychovávala městské a venkovské ranhojiče a také školila porodní babičky.

$\mathrm{V}$ Brně probíhala výuka porodnictví německy, v Olomouci od roku 1804 pak probíhala už česky i německy. Zpočátku učili porodnictví profesoři anatomie. Marně se pokoušel první z nich $G$. Feichter zajistit možnost výuky porodních babiček u lůžka tak, aby $\mathrm{v}$ některém špitále bylo $\mathrm{k}$ dispozici 6 postelí pro chudé rodičky, které by tu rodily zdarma a u nichž by se budoucí babičky mohly učit. Návrh byl zamítnut. Teprve $\mathrm{v}$ nemocnici, slavnostně otevřené v roce 1787 , byla možnost výuky u lůžka. Byla tu porodnice se 14 lůžky pro těhotné, s dvěma pro rodičky a dvaceti pro šestinedělky. Chudé rodičky zde rodily bezplatně, za to se musely zavázat, že zůstanou určitou dobu jako kojné za stravu, pivo a 2 krejcary denně.

$\mathrm{V}$ archiváliích univerzity $\mathrm{v}$ Olomouci se zachovaly záznamy o studujících porodních babičkách - je znám přesný počet studujících, jejich úspěch, či neúspěch při přísné závěrečné zkoušce:

- roku 1783 zde studovaly 3 žákyně

- roku 1784 z pěti dvě propadly

- $\quad$ roku 1785 ze 39 propadlo 27

Za Feichtera bylo aprobováno 175 a do konce roku 1803 celkem 185 porodních babiček. Ranhojičů-porodníků za tuto dobu bylo aprobováno 302 (Státní okresní archiv v Olomouci).

$\mathrm{V}$ následujících letech počet zapsaných babiček stoupal.

- do roku 1828 bylo aprobováno již 1286 babiček

- do roku 1867 bylo aprobováno 2476 babiček

Seznamy jsou abecedně sestaveny, je uvedeno místo narození a bydliště; jsou zapsány zaplacené poplatky za zkoušky (3 zl.), př́padně jejich prominutí, resp. že poplatky zaplatila vrchnost nebo domovská obec. Většina (asi $75 \%$ ) porodních babiček prijatých ke studiu je české národnosti, někdy jsou všechny české národnosti (např. v letech 1877 a 1895), někdy naopak všechny jsou národnosti německé (např. roku 1861). Německé uchazečky přišly většinou ze Slezska, z Haliče nebo z Uher. Všechny však musely umět a rozumět pro praxi česky a německy. Vždy je uvedeno, zda jde o dívku svobodnou, vzácně $(1857,1859)$ je tu i řádová sestra, jindy (1858) dvě z třetího řádu sv. Františka, jednou (1860 a1874) vždy jedna izraelitka. Věk se pohyboval od 21 do 46 let, 
svobodná byla jen asi 1/10 zúčastněných. Roku 1888 studovaly 4 řádové sestry.

Kurzy probíhaly dva ročně, jeden začínal 1. října, druhý 1. března. Praxe byla vždy v nemocnici (vyšetřování, ošetřování, péče o děti $\mathrm{v}$ nalezinci), praxe dopoledne od 8 do 11 a odpoledne od 14 do 16 hodin; výuka vždy jednu hodinu v úterý, středu a sobotu od 11 do 12 , v pondělí, čtvrtek a pátek od 16 do 17 odpoledne. Přednášky se konaly $\mathrm{v}$ tehdejším německém gymnáziu $\mathrm{v}$ bývalé aule univerzity. Výuka probíhala i v létě, profesor neměl nárok na prázdniny a nesměl se bez dovolení vzdálit.

Od uchazeček se vyžadoval křestní list, domovský list, vysvědčení o mravech od obce nebo farního úradu. Roku 1880 činila taxa už 31 zl. 22 a půl kr. Uchazečky mladší 24 let musely mít svolení ministerstva, žádná nesměla být př́ přijetí starší 45 let. Musely být zdravé a - zvlášt' je zdůrazněno - mají umět číst a psát. Ještě 11. března 1886 byla Ludmila V., která žádala o přijetí do školy, odmítnuta, protože neuměla číst a psát. Roku 1873 byla odmítnuta jedna uchazečka, protože byla kdysi trestána pro krádež (Státní okresní archiv v Olomouci).

Největší zásluhy o výuku porodních babiček měli nesporně F. J. Mošner, V. Vyšín a F. Groh. Učili podle pražské učebnice Jungmannovy a jeho dalších monografií, ale také podle Steideleho a samozŕejmě hlavně podle „Babictví“ F. J. Mošnera, které vyšlo ve dvou vydáních roku 1830 a 1848 . K tomu pŕistoupily učebnice L. F. Froriepa a K. T. Tormaye.

$\mathrm{S}$ žákyněmi byly i různé nepř́jemné starosti. Roku 1876 byla ze školy vyloučena Marianna G. Pro nemravné chování, protože - ač vdaná chodila po nocích s vojáky a sháněla lék proti kapavce...

Po skončení studia a úspěšném složení závěrečných zkoušek skládala absolventka povinnou prrísahu babskou. V sedmdesátých letech byla prísaha zkrácena, a to tak, že byl přečten text: „Slibite, že těhotným, rodičkám a šestinedělkám, k nimž budete povolána ku pomoci, a to jak chudým stejně jako bohatým, s tímto zde naučeným uméním budete nápomocna a že při tom věrně a svédomitě splnite všechny povinnosti, které jsou porodni bábě skrze zákony a predpisy a zvláštními instrukcemi predepsány. " Načež musela slibující opakovat: „Co mi zde bylo prečteno, tomu jsem přesné rozuméla a slibuji to dodržeti “. $\mathrm{Na}$ to následovalo podání ruky.

Po složení slibu obdržela absolventka diplom, zprvu německý. Roku 1880 se stala tato skutečnost předmětem kritiky - bylo poukázáno na to, že je podivné, aby absolventky českého oddělení porodnické školy dostávaly německý diplom. Prof. Groh to vysvětloval tak, že diplom je vlastně jen pro úrední potřebu. Přesto však 22. prosince 1880 nařídilo místodržitelství vydávat diplomy v češtině.

Také dodržování antisepse bylo dlouho iluzorní. Semmelweisův objev $\mathrm{k}$ zábraně tak často smrtelné horečky omladnic, spadající do konce čtyřicátých let 19. století a publikovaný v šedesátých letech, čekal nejen v Olomouci na správné zavedení do praxe. Teprve vyhláška z 28. října 1878 nařizovala, že každá porodní babička musí mít roztok kyseliny karbolové, který si sama pripraví tím, že rozpustí 10 gramů krystalické kyseliny karbolové v půl litru vody; tímto roztokem si měla mýt ruce, než se dotkla rodidel těhotné, rodičky nebo šestinedělky. Taktéž měla tímto roztokem umýt nástroje. Vyhláška byla rozdávána proti podpisu absolventkám při složení slibu a byla $v$ zásobě ve 400 německých a 600 českých výtiscích (Chytilová, 2005, s. 53-57).

Žákyně se měly samožrejmě učit vyšetření a vedení porodu na preparátu pánve (fantomu). Až roku 1885 se dovídáme ze zápisu, že profesor Vyšín poukazoval potřebu takovouto pánev zakoupit, protože škola má $\mathrm{k}$ dispozici jen pánev mužskou. Pražská firma Waldek a Wagner proto nabízí různé pánve (pravidelnou ženskou pánev z papíroviny za 16 zl., fantom kožené ženské pánve bez bez dětského fantomu za 90 zl. a s dětským fantomem za 100 zl., ba i dvojčata rozdílného rodu po $7 \mathrm{zl}$.), mimo to měŕítko pánve a dělohy za 10,50 zl. či úplný ženský skelet za 75 zl. Roku 1894 jsou zakoupeny obrazy placenty dvojčat, kufr pro porodní bábu s klystýrovou stříkačkou a Soxlethův sterilizační aparát.

Škola byla také informována o řadě zvláštních př́hod. Tak např. roku 1855 byla rozhodnutím krajského soudu $\mathrm{v}$ Brně odsouzena porodní bába Marianna M. pro zabití dítěte ke dvěma letům těžkého žaláře. Roku 1880 byla pro vraždu odsouzena $\mathrm{k} 18$ měsícům těžkého žaláře Valentina P. a odebrán jí diplom. Roku 1890 udala Magdalena L., že v Zábřehu provozuje praxi Marianna S. s falešným diplomem. Závažné bylo také roku 1888 ohlášené zjištění opavského okresního lékaře, že absolventky olomoucké školy vykazují některé závažné ne- 
dostatky ve svých znalostech. Sděluje, že neznají předpisy, používané $\mathrm{k}$ dezinfekci čpavku a melissových kapek, používají oční stř́kačky a znečištěné houby, takže děti mají záněty spojivek atd. Byla proto nařízena a provedena kontrola a $\mathrm{z}$ nařízení ministerstva vnitra a místodržitelství byly provedeny opakovací kurzy pro porodní báby $\mathrm{v}$ praxi, zvláště se zřetelem $\mathrm{k}$ antisepsi a $\mathrm{k}$ zábraně horečky omladnic, o níž měly báby nedostatečné znalosti.

Je ovšem problematické, zda bylo možno všechny nedostatky ve vědomostech u praktikujících porodních bab připsat na vrub výuce na olomoucké škole. Je známo, že pracovalo roku 1823 v brněnském kraji ještě 248 nezkoušených - tedy pokoutních - porodních babiček, v kraji olomouckém jich bylo $\mathrm{v}$ tomto roce $29, \mathrm{v}$ prerovském 51, v opavském 19 a v těšínském 5. 22. července 1825 bylo moravskoslezským guberniem nařízeno, aby do matrik (křtících knih) bylo u každého dítěte zaznamenáno, která bába byla při porodu, a aby tyto zápisy byly úředníky kontrolovány, aby „nezmocněné“ báby byly pokutovány, ba i trestány žalářem.

V dubnu 1870 se uvažuje o zrušení olomoucké porodnické školy spolu se zrušením medicínsko-chirurgického učiliště. Škola v Olomouci zůstala; ale roku 1874 vyžadovalo místodržitelství zprávu, co by potřebovala porodnická škola $\mathrm{v}$ př́padě přeložení do Brna. Bylo by třeba jednoho profesora, dvou asistentů, dvou sekundárních lékařu a dvou školních porodních babiček; zajistit též hospitalizaci chudých rodiček na osm dní zdarma, aby pak mohly být zařazeny jako kojné, a konečně by bylo třeba zajistit inspekci pokojů, kuchyně, vedení knih, očkování proti neštovicím i pitvání.

Nic nebylo rozhodnuto, ale 1. října 1876 byla znovu zvažována možnost stěhování do Brna. Dnem 19. května 1881 byl datován další rozbor prof. Groha, který zdůrazňoval, že olomoucká porodnická škola patř́ k nejvíce navštěvovaným v celé monarchii a přeložení do Brna by nepřineslo žádné úspory, bylo by jen poškozením celé věci. Nicméně se o tom na místodržitelství stále uvažovalo. Škola v Brně byla zrrízena $\mathrm{v}$ roce 1882, ale 11. května 1889 se $\mathrm{v}$ prrípisu prof. Vyšína poukazuje, že škola v Olomouci je výhodná pro žákyně ze Slezska a reforma vyžaduje školy dvě: v Olomouci a v Brně. Škola v Olomouci zůstala a spolu $\mathrm{s}$ nemocnicí i porodnicí se přestěhovala v devadesátých letech na Tabulový vrch (porodnice měla v roce 189971 lůžek a škola v českém a německém kurzu vždy 70-80 žákyň ročně) (Wondrák, 1993).

Práce porodních bab mimo školu a mimo porodnici v Olomouci (ve městě i v okoli). Většina žen rodila doma. Zprvu proto, že nebyla jiná možnost - nemocnice a porodnice nebyly pak proto, že domácí péče byla považována za lepší a důstojnější. Protože se do porodnice uchylovaly hlavně chudé rodičky, takže žena, která si to mohla dovolit, si zajistila porod a péči doma. Později prristoupil také pocit určitého většího bezpečí před infekcí a horečkou omladnic. Porody doma vedly porodní báby, doktoři medicíny, porodníci a ranhojiči- porodníci.

Magistrát města Olomouce měl roku 1803 zajistit, aby v každé obci, která přináležela městu jako vrchnosti, byla porodní bába. Tak se dochoval seznam zkoušených diplomovaných bab v Holici, Unčovicích, Moravské Loděnici, Křelově, Horce, Cholině, Mezicích, Grycově a Slušovicích. Ty dostaly každá 15 zl. Nezkoušené ze Skrbeně, Hynkova, Lubenic, Dubčan, Blatce, Hněvotína a Nových Sadů byly poslány ještě na školení. Zkoušeny musely být $\mathrm{v}$ lyceu a pak měly dostat také 15 zl. Báby z Nemilan, Bystrovan a druhá z Hněvotína neuměly číst a nemohly se učit. Za dva roky (1805) jim všem byly dopřány další podpory ve výši od dvou do $18 \mathrm{zl}$. podle velikosti obvodu, roku 1819 dalších 12 zl. 30 kr., což se od následujícího roku stalo pravidelným ročním př́spěvkem.

O místo porodní babičky v samotném městě Olomouci byl značný zájem. V archiváliích je od roku 1786 do roku 1873 celkem 141 žádostí o povolení vykonávat ve městě živnost porodní báby. Podle jmen lze jen těžko rozlišit jejich národnost už proto, že jména jsou psána německy; celé žádosti jsou psány písařem a někdy podepsány třemi krŕížky. Vždy je uvedeno bydliště, číslo domu, jméno a povolání manžela, př́padně, že jde o vdovu a počet dětí. Přiloženo je potvrzení o beztrestnosti. Muselo jít vždy o křest'anku (aby pokřtila dítě v prrípadě nutnosti) a ženu silnou.

Usazené porodní asistentky byly podřízeny krajskému úřadu, musely mít označené bydliště, být $\mathrm{k}$ dispozici ve dne i v noci, byla jim přikazována mlčenlivost, povinnost při těžkých porodech včas volat lékaře, děti ohrožené na životě 
křísit, uvolnit jazyk a event. pokřtít. Zvlášt' se zdůrazňoval zákaz potratů.

Počet porodních asistentek v Olomouci:

- $1822-21$

- $1837-26$

- $1847-24$

- $1884-34$

- $1918-15$

Ani Olomouci se nevyhnuly pŕíhody, zaviněné někdy neznalostí či nedostatkem dobré vůle. Jedna $z$ nejtěžších př́hod, která se udála 10. listopadu 1787 na Nové Ulici a byla soudně projednávána, zaujímá 21 stran protokolů. Šlo zcela zřejmě o zanedbanou příčnou polohu u 29 leté rodičky Barbory G. a porodní bába Marianna R., údajně zkoušená v Brně, nezavolala žádného porodníka, nýbrž kuchyňským nožem uř́zla dítěti vyhřezlou pravou ruku. Při výslechu vypovídala, že dítě už čtyřri hodiny nevykazovalo žádné známky života. Udání podal ústně ranlékař a ohledač Jakub Hechtl, který mluvil taky o mrtvém dítěti, ale o levé paži. Lékař byl přivolán později než duchovní. Soud zasedal v únoru 1788, žádný znalecký posudek nebyl předložen, porodní bába byla „suspendována“, měla nadále povoleno praktikovat „,na predměsti““ a v srpnu téhož roku je uvedena v seznamu osmi návštěvnic školení v Moravské Třebové. Skládá tam zkoušku a protokol podepisuje třemi krřžky... (Wondrák, 1993).

\section{František Jan Mošner}

Žil v letech 1797-1876 byl prvním českým profesorem porodnictví na bývalém medicínskochirurgickém učilišti, rektor někdejší Františkovy univerzity a ředitel nemocnice v Olomouci. Studoval lékařskou fakultu pražské univerzity a studia dokončil v roce $1823 \mathrm{~s}$ titulem magistra porodnictví. Zajímal se nejen o medicínu, ale také o chemii, národní hospodářství a řeči (vedle mateřské češtiny ovládal plynně němčinu, francouzštinu a italštinu). Pracoval jako asistent na porodnické klinice u profesora A. Jungmanna. O tři roky později, roku 1826 byl prohlášen doktorem lékařství a chirurgie. Poté působil jako městský fyzik v Benešově a roku 1829 získal místo profesora porodnictví na medicínskochirurgickém učilišti v Olomouci. Po příchodu do Olomouce přednášel prof. Mošner teoretické a praktické porodnictví, které zůstalo jeho hlavním oborem. Roku 1834 se stal rektorem tehdejší Františkovy univerzity v Olomouci. O dva roky později vyšla jeho učebnice „Babictvi““ - v úvodu se popisuje rozdílná funkce porodníka a porodní báby. Té jsou svěřovány normální porody, přesto však musí znát veškerou patologii, aby věděla, kdy má zavolat porodníka a kdyby nebyl náhodou ihned po ruce, aby dovedla okamžitě pomoci $\mathrm{v}$ př́padě akutního ohrožení plodu nebo matky. Velký oddíl je věnován pojednání o výběru osob vhodných pro babictví a velmi podrobně jsou zde vyjmenovány vlastnosti, které má bába mít. Vlastní učební látka je rozvržena, jak bylo zvykem, na normální a patologické porodnictví a rozdělena do číslovaných kratších kapitol. Značnou pozornost věnoval Mošner výkladu o ošetření novorozence a péči o kojence.

Při porodu bylo středem zájmu rodičky i báby, aby nedošlo k ruptuře hráze, protože její poranění se prakticky nešila. Podpírání hráze popisuje Mošner velmi podrobně, pravděpodobně s úmyslem, aby si porodní bába $\mathrm{v}$ učebnici četla, a tak si upevňovala znalosti získané v kurzu. ,,Roztrhla-li se hráz, po celé živobytí zůstala rodička mrzákem “.

Z nepravidelných porodů jsou velmi přesně popisovány mechanismy při deflexních polohách, které mohla vést i bába.

Termíny, které Mošner ve své knize užívá:

- $\quad$ varhy nebo hanbypysky - stydké pysky

- $\quad$ špidla - záhlaví

- poutec - temeno

- ciply - tepny

- krvoval - velký krvotok

- materník, matka, dětinec - děloha (termín děloha se v Mošnerově době neužíval)

\section{Instrukce pro porodní báby ( $\mathrm{z}$ let 1726-1792 )}

1. Pŕijímání bab - pro nezkušenost bab již mnohý obyvatel země zahynul, proto takový úřad nesmí vykonávat osoba, která vědomosti a zkušenosti $\mathrm{k}$ tomu nemá a musí být zkoušená od „Mistra a učeného v babství" nebo prri jejich nedostatku krajským nebo městským lékařem

2. Obstarání dostačujícího počtu bab - starostí vrchnosti bude, aby v zemi vždy byl dostatek takových zkušených bab - pokud ne pro každou dědinu, alespoň pro 2 nebo 3 obce se jedna bába ustanovit musí

3. Povinnost bab je také střídmost a stř́zzli- 
vost - taková od vrchnosti schválená bába má vést poctivý, křest’anský, střídmý a stř́zlivý život; musí ona každou hodinu ve dne $\mathrm{v}$ noci $\mathrm{s}$ pomocí prispěti hotova býti; nemá se „silným nápojem přepojiti“, protože na ní závisí životy osob

4. Další povinnost $\mathrm{v}$ jejich úřadě - převážně mají být mlčenlivé a mezi sebou mají mít porozumění, svornost; jedna druhou nemá nenávidět, naopak mají si přispět radou i skutkem; v př́padě nouze mají žádat lékaře, jinak takové zanedbání se bude trestat pokutou a sesazením $z$ úradu jejich

5. Péče o křtění dítěte

6. Báby se mají varovati pod těžkým trestem odhánějící nebo nebezpečné prostředky dávati a raditi - bába se nemá nechat zaslepit vidinou peněz a plod života odehnati pod těžkými tresty jako ztracení úřadu, cti a jinými tresty na těle neb živobytí; žádné osobě nesmí podat lék, nápoj, prášek neb $\mathrm{k}$ tomu radit; pokud by bábě bylo vyhrožováno, povinností její je to vrchnosti oznámit

7. Báby se mají kurýrování varovati - bába nesmí nikoho léćit, výjimkou je pomoc nedělkám a novorozeným dětem, pokud by to bylo potřeba, nemohouce lékaře dosáhnout (Chytilová, 2005, s. 90-91).

$\mathrm{V}$ roce 1895 byl otevřen Ústav hraběte Pöttinga, který byl zaměřen na vzdělávání dívek, od počátku zde byla literní a obchodní škola a kurzy šití, vaření, malování na porcelán...). V roce 1905 se nabídka rozšírilla a nacházely se zde školy: literní, pokračovací vyšší dívčí, obchodní, průmyslová, kuchařsko-hospodářská, jazyková a hudební a kurzy: malba - kresba, malba porcelánu, umělecké vypalování dřeva, šití, tanec, pravopis a krasopis.

$\mathrm{V}$ roce 1912 vydalo c. k. ministerstvo veřejných prací organizační a učební osnovy pro nový typ školy a vznikla Vyšší škola pro ženská hospodářská povolání, vyučování bylo zahájeno 27. 7. 1914, délka studia byla 3 roky. Její absolventky se uplatnily $\mathrm{v}$ nemocnicích, lázeňských domech, sirotčincích, dětských opatrovnách, ústavech pro choromyslné, sanatoriích...V roce 1929 vznikl nový název - Vyšší dívčí škola.

$\mathrm{Na}$ základě zákona o základní úpravě jednotného školství (95/1948 Sb.) byly 10. 5. 1948 otevřeny 2 ročníky sociálně zdravotní školy, to je začátek zdravotnické školy.

Potom následovaly další změny zákonů a také názvi̊ školy:

- Školní rok 1949/1950 - Vyšší sociálně zdravotní škola v Olomouci, byly otevřeny obory porodní asistentka, zdravotní sestra, zdravotní pracovnice, studium trvala 4 roky.

- Školní rok 1950/1951 - začaly se vyučovat další obory - dětská sestra, zdravotní laborant, rentgenologický pracovník

- Školní rok 1951/1952 - Vyšší zdravotnická škola v Olomouci, studium bylo zkráceno na 3 roky (byl nedostatek zdravotníků v praxi, problémem však byl velmi nízký věk nastupujících do provozu - často jim bylo teprve 17 let).

- Školní rok 1955/1956 bylo studium znovu prodlouženo na 4 roky. Na přelomu 50.-60. let 20. století se začínaly otevírat trrídy dvouletého studia pro absolventy SVVŠ (střední všeobecně vzdělávací škola - jako nyní gymnázium) jako tzv. pomaturitní studium. Bylo určeno pro obory: porodní asistentka, zdravotní sestra, rentgenologický laborant a rehabilitační pracovník.

- V roce 1960 byl ustaven zákon o soustavě výchovy a vzdělávání (186/1960sb.) - jednotný školský systém, vznikla Střední zdravotnická škola v Olomouci. Vznikaly další studijní obory (Fišara, Hovorková, Nauková, 1995, s. 5-25).

- Při příležitosti 100. výročí založení Ústavu hraběte Pöttinga byl škole v říjnu 1995 propůjčen název Střední zdravotnická škola Emanuela Pöttinga.

- Ve školním roce 1996/1997 byla vedle Střední zdravotnické školy také Vyšší zdravotnická škola Olomouci. Studijní programy dostaly název diplomovaná porodní asistentka, diplomovaná všeobecná sestra... Studium bylo pro absolventy středních škol s maturitou a trvalo 3 roky.

- K 1. lednu 1997 byl změněn název na Střední zdravotnická škola a Vyšší zdravotnická škola Emanuela Pöttinga (Fišara, 1998, s. 7).

- Ve školním roce $2002 / 2003$ byli prijati poslední uchazeči do oboru diplomovaná porodní asistentka. 
Studium porodních asistentek ve 20. století bylo 4leté pro absolventy ZDŠ (základní devítiletá škola), 2leté pro absolventy SVVŠ, gymnázií a později i jiných středních škol s maturitou nebo 1leté jako doplňkové pro zdravotní sestry pracující na gynekologicko-porodnickém oddělení. Studium čtyřleté bylo ukončeno $\mathrm{v}$ roce 1975, studium 2leté pomaturitní bylo ukončeno v roce 1995. Po vzniku vyšších odborných škol zdravotnických bylo studium 3leté pro absolventy středních škol s maturitou, které bylo ukončeno v roce 2005. V roce 1965 došlo ke změně názvu z porodní asistentky na ženskou sestru, v roce 1990 z ženské sestry na porodní asistentku.

Jména některých vyučujících porodních asistentek, které působily na SZŚ a VZŠ v Olomouci - Mgr. Josefa Koudelková, Ludmila Zaoralová, Eliška Kvasničková, PhDr. Ludmila Hejtmánková, Mgr. Jana Čurdová, Mgr. Renáta Hernová, Ph.D., Mgr. Věra Vránová, Ph.D.

Studium porodních asistentek se ve 21. století vrací na akademickou půdu.

$\mathrm{Na}$ Lékařské fakultě Univerzity Palackého $\mathrm{v}$ Olomouci byl $\mathrm{v}$ akademickém roce 2002/2003 otevřen bakalářský studijní program Ošetřovatelství, obor Porodní asistentka v prezenční formě studia. Studijní program odpovídal směrnicím Evropské unie a prošel akreditací.

Poslední reakreditace byla v roce 2008 a studijní program doznal změny názvu na Porodní asistence, obor Porodní asistentka a došlo $\mathrm{k}$ rozšíření akreditace pro kombinovanou formu studia.
Studijní program přešel od akademického roku 2008/2009 na nově vzniklou Fakultu zdravotnických věd a je garantován Ústavem porodní asistence. V současné době (stav ke 30. 6. 2008) je 84 absolventek porodních asistentek bakalářek. V akademickém roce 2008/2009 je ve studijním programu 75 studentek a 1 student $\mathrm{v}$ prezenční formě a 47 studentek v kombinované formě studia. Vyučujícími jsou porodní asistentky Mgr. Věra Vránová, Ph.D., a Mgr. Ludmila Reslerová, Ph.D., a porodní asistentky mentorky na Porodnicko-gynekologické klinice Fakultní nemocnice v Olomouci.

\section{LITERATURA}

FIŠARA, V., HOVORKOVÁ, I., NAUŠOVÁ, A.: $\mathrm{Z}$ historie Pöttingea. In: Almanach ke 100. výroči založeni Ústavu hraběte Pöttinga v Olomouci. Olomouc: SZŠ, 1995. s. 203.

FIŠARA, V.: Vývoj školy od roku 1990. In: Dodatek k almanachu 100 let Pöttingea Olomouc. Olomouc: SZŠ a VZŠ E. Pöttinga, 1998. s. 75.

CHYTILOVÁ, S.: Profese porodních bab v historii. $B a-$ kalárská práce. Olomouc: LF UP, 2005. s. 95.

Státní okresní archiv v Olomouci. Archiv města Olomouc. Zlomky registratur 1726-1792. Různá tištěná nařízení. Inv.č. 1847, č. kartonu 78.

Státní okresní archiv v Olomouci. Archiv města Olomouc. Zlomky registratur 1726-1792. Organizační statut nemocnice, porodnice a nalezince. Inv. č. 1629, č. k. 66 . Státní okresní archiv Olomouc. Archiv města Olomouc. Instrukce pro porodní báby (1726-1792).

Zlomky registratur 1426-1786 (1843). Inventární číslo 1847, číslo kartonu 78.

Státní okresní archiv Olomouc. Archiv města Olomouc. Zlomky registratur 1426-1786 (1843). Organizační statut nemocnice, porodnice a nalezince v Olomouci 1787. Inventární ćíslo 1629, číslo kartonu 66.

WONDRÁK, E.: Z historie porodnictví v naši zemi. Ročenka SOA v Olomouci 2, 1993.

Věra Vránová e-mail:vranova@tunw.upol.cz 